\title{
"Dangerous" Beauty: Imagining the Other in the Noh Play Sesshōseki
}

Dunja Jelesijevic

Northern Arizona University

Nasu district in Japan's Tochigi prefecture represents a major tourist draw, owing to its picturesque scenery of the Nasu volcanic mountain range, Nikkō National Park, and the popular complex of sulfur hot springs, collectively known as the Eight Springs of Nasu (Nasu Hachiyu). The latter, in particular, evokes an association with a local tradition about a rock that emits noxious gasses causing all living beings who come close to it to perish. ${ }^{\mathrm{I}}$ The legend of the murderous rock was at one point married with another, pan-Asian, folk motif, that of a fox enchantress, and a tale was spun of possession, punishment, and redemption that cuts across genres of medieval and early modern Japanese literature, finding its way onto the Noh stage in the fifteenth-century play Sesshoseki ("The Killing Stone").

Drawing on multiple strands of the varied retellings, the Noh play weaves its narrative together by positioning two distinct voices opposite (but not against) each other: on the one hand, the spirit of the stone, which moves through multiple identities, shifting shape and traversing time and space, and on the other, an itinerant Buddhist monk tasked with identifying and appeasing the spirit, thus providing the narrative with resolution and completion. However, as is frequently the case in Noh, the resolution and

I The rock believed to be the legendary "Killing Stone" still exists today and represents a local tourist attraction. Even a cursory internet search will yield a plethora of results on commercial travel-related web pages, personal blogs, and the like, showing that local tourist organizations continue to capitalize on the legend of the "Killing Stone."

How to cite this book chapter:

Jelesijevic, D. 202r. "Dangerous" Beauty: Imagining the Other in the Noh Play Sesshōseki. In: Jonsson, H., Berg, L., Edfeldt, C. and Jansson, B. G. (eds.) Narratives Crossing Borders: The Dynamics of Cultural Interaction. Pp. I 89-206. Stockholm: Stockholm University Press. DOI: https://doi .org/IO.I6993/bbj.i. License: CC-BY 4.0 
completion in Sesshōseki are anything but straightforward. The two protagonists have more in common than it seems, while their (op)positioning vis-à-vis one another is revealed to be of a different kind than initially presented. Both figures are carefully discursively constructed as occupying and negotiating liminal spaces as well as liminal modes of being. They are both creatures of movement and transformation, engaged in crossing, transgressing, transcending, and reestablishing various sets of boundaries (spatial, temporal, and ontological). By presenting its protagonists in this way, Sesshōseki questions and upsets the overlapping orders (social, political, and religious) within which it takes place. I suggest that exploring the motifs of movement and transformation as particular modes of boundary-crossing in Sesshōseki provides insight into how the concept of boundary-crossing is utilized by the text to bring about and respond to these questions and upsets. In turn, such exploration illuminates some peculiar ways in which the very act of boundary-crossing is being narratively and discursively negotiated through the medium of Nob theater. This analysis of Sesshōseki provides a case study of how, through patterns of both following and subverting the generic conventions, Noh play ritualizes those crossings, thus becoming a locus for exercising and working through multiple layers of boundary crossing, and I suggest that observing how Nob ritualizes these processes offers novel ways into looking at the very nature of boundary-crossings and the modes of their actualizations.

\section{Mover and Shaker: Woman, Fox, Demon, Goddess}

In the Noh canon, Sesshoseki is a fifth-category demon play ${ }^{2}$ of uncertain authorship. ${ }^{3}$ Following the typical structure of a

2 The five-category structure of Nob plays (gobandate 五番立; God, Warrior, Women, Miscellaneous, Demon) is codified sometime in the Edo period (I600-г 868). When performed as entertainment in official setting (before the Shōgun etc.), the full program would consist of five plays, one category each, plus the Okina piece and four Kyogen comical plays (Brazell, I999, p. 530).

3 The authorship of the play is most frequently listed as anonymous, but one source attributes it to the playwright Saami (佐阿弥) (Sanari, I930, p. 1633$)$. 
mugen-Noh play, ${ }^{4}$ it opens with a michiyuki, a travel sequence, introducing a Buddhist priest Gennō, ${ }^{5}$ who is passing through Nasu-no-hara in Shimotsuke province. There he notices birds falling to the ground as they fly over a particular stone in the field. While he ponders this curiosity, a woman mysteriously appears, warning him not to get close to the stone as it causes death to all living creatures who approach it. Prodded by Gennō, the woman proceeds to narrate the legend of the stone. The story is about Lady Tamamo (Tamamo no Mae), an exquisitely beautiful, sophisticated, and learned lady of the court and a favorite of the emperor Toba. ${ }^{6}$ Following an extraordinary event in the imperial palace, where Tamamo's body miraculously began emitting light, the emperor fell ill. Abe no Yasunari, the court onmyōji, realizes that the two events are related, whereupon he identifies Lady Tamamo as the incarnation of an evil fox-spirit. She is then hunted down in her vulpine form and killed, but the spirit of the fox possesses a stone in the field. From that point forward, the stone

4 Mugen Nob (夢幻能) translates to “dream Nob" or “fantasy Noh." It is a type of Nob play situated in a supernatural or dream world. A mugen Nob play typically begins with a religious figure visiting a significant locale. There, he encounters a local person whose words and demeanor signal that there is something extraordinary or significant about them, and it is hinted that they are somehow connected to the locale and its history. The end of the first act concludes with the local person revealing their true identity as the ghost associated with the place, upon which they disappear. It is then usually hinted that the priestly figure will spend the night at the locale (hence "dream" Nob - it is deliberately left ambiguous whether the events of the play take place in actuality, or in a dream-world), and during the night the ghost returns, asking for rites of repose.

5 Gennō Shinshō 源翁心昭 (I329-I400), Buddhist monk of the Sōtō Zen lineage.

${ }^{6}$ Emperor Toba 鳥羽天皇, reigned II07-II23; held the office of the retired emperor.

7 Yin-yang diviner; practitioner of Onmyōdō. Onmyōdō 陰陽道, translatable as "The Way of Yin and Yang," refers to a system of beliefs and practices based on the Chinese yin/yang philosophy that was in Japan supplemented with teachings and rites from Esoteric Buddhism, as well as local, Kami-worship-associated beliefs and practices. While the Abe family was historically in charge of Onmyōdo activities at the Japanese court, Abe no Yasunari is a fictitious character. For more on onmyōdō, see Butler (I996). 
starts to exhibit its deathly effect and comes to be known as the "Killing Stone (sesshōseki)." The mysterious woman completes her story and reveals, as she disappears, that she is the ghost of Lady Tamamo.

The second act follows Gennō as he conducts a memorial service for the spirit of the stone in order to lead it onto the Buddha's Path. The Killing Stone splits open, and the spirit of the fox appears from within the stone in its demonic form. The spirit then recollects its past, revealing herself as a malevolent force that throughout centuries caused empires to crumble by taking on a form of a beautiful woman and seducing their rulers. Her cathartic narrative ends in a solemn promise to abandon her evil ways, leaving the stone behind as a symbol of the firmness of her decision. Due to Gennō's prayer, the spirit is appeased. ${ }^{8}$

On the surface, Sesshōseki is a straightforward tale of Buddhist conversion. It is framed as a triumph of the Buddhist religious regimen over the ultimate Other, a danger from Without who had bended time and space with the intention of bringing an end to both human and divine orders. The ghost of Tamamo herself states as much in the denouement of the play:

What should I hide now? In India, I was the tomb deity worshipped by the crown prince Hanzoku; in China, I appeared as Hōji, the consort of King Yū; in our realm of Japan, I became Lady Tamamo, consort of the emperor Toba. Intent on toppling the imperial and the Buddhist law, I transformed into a beautiful woman [...] having remained in this field, having become the killing stone, I claimed people`s lives for many a year. Today, however, having received Buddha's Law, I shall cease committing evil deeds. The stone remains as a symbol of my firm promise to you, reverend priest, and the form of the demon is gone. ${ }^{9}$

Tamamo's concluding monologue brings together two main narrative threads at the basis of the play: her history as the destroyer of kingdoms which culminates at the court of the emperor Toba, and her subsequent destiny of being discovered as the fox spirit and ending up trapped inside the Killing Stone.

\footnotetext{
${ }^{8}$ For this essay, I consulted two versions of the play, Sanari Kentaro's text in Yōkyoku taikan and Ito Masayoshi's annotated version in Yōkyokushū.

9 Translation mine. (Sanari, I930, p. I644)
} 
As a stand-alone narrative, the former thread has been reproduced in a series of retellings, one of the earliest being in the fourteenth-century historical chronicle Shinmeikagami, and then later in several versions of short-story collections Otogizōshi (Yokoyama \& Matsumoto, I98 I, p. I3-58), but it is itself a combination of several thematic units from earlier sources. The tale of the seduction of King Yù of China which brings his reign to ruin is in Japanese sources found in the thirteenth-century Jikkinshō ("A Miscellany of Ten Maxims") and the fifteenth-century Genpei jōsuiki ("The Record of the Rise and Fall of the Genji and Heike Clans") a variant text of the Kamakura period (I I 85-I333) epic Heike monogatari ("The Tales of the Heike"). In his analysis of the worldviews of Josuiki, Minobe Shigekatsu suggests that the telling of the legend of king Yù and his fatal consort in this work parallels and, thereby, has the function of framing the downfall of Taira no Kiyomori in a very specific way. Kiyomori was the leader of the ill-fated Taira (Heike) clan, tragically defeated in the Gempei War (II80-II85), which marked a seismic shift in Japanese history, completely reconfiguring the social, political, and cultural landscape of Japan at the time. Josuiki, Minoru argues, shows how the narrative of the Heike is placed in a religious framework of an attempt to reorient the court-sponsored worship from old gods to new, depicting Kiyomori's worship of an "alien" deity, which, the text implies, may have caused his demise that precipitated the dramatic transformation of the entire realm (Minobe, 1982, p. 220-23I). The deity in question takes the form of a fox and is known in Japan as Dakiniten, but is originally a part of the South Asian Tantric (both Buddhist and Hindu) traditions (Faure, 20I 5, p. I I7-I 22).

The original tale of Yù's consort as given in Chinese sources ${ }^{10}$ does not contain references to foxes, but in Japanese texts such as

ro $\mathrm{Y} \overline{\mathrm{u}}$ is the Japanese pronunciation of the name of the King You of Zhou 周幽王 $(78 \mathrm{I}-77 \mathrm{IBCE})$. The earliest records of You and his consort are found in Shu-king ("The Book of Documents"), while Ssu-ma Ch'ien gives the account in Shih chi ("The Grand Scribe's Records"), in which king You's consort Pan-ssu is described as contributing to the fall of Eastern Zhou by enchanting the king with her beauty and causing him to become reckless and negligent. 
Jossuiki, it is blended with other traditional Chinese tales involving fox enchantresses, and the implied association is rendered explicit in the legend of Lady Tamamo. ${ }^{\text {II }}$ The account of "seduction" of Hanzoku in India and its inclusion in the Tamamo narrative rests on similar logic. In this story inspired by Ninōgyō ("The Benevolent King Sutra"), the spirit does not materialize as a beautiful woman, but is actually the deity Tsuka no Kami (lit. "god of graveyards") worshipped by the prince. ${ }^{12}$ This deity is identified with the same Dakiniten worshipped by Taira no Kiyomori and purported to be both the cause of his ascent and his extraordinary downfall. Therefore, just as King Yù fell to his demise after being seduced by a supernatural fox, Kiyomori was likewise "seduced" by a fox deity, an alien - Other - force, while Hanzoku succumbed to the promise of power and might by a beastly deity of graveyards, whose domain literally is Other (world). In Japan, Emperor Toba falls prey to the incarnation of the same mysterious supernatural force, enticed both by the beauty and the power of a mysterious lady who materialized in his court seemingly out of nowhere. It is not only his reign that is endangered, but his very life, and only upon the intervention of the powerful onmyōii, Abe no Yasunari, is the threat, seemingly, mitigated. It is worth noting

II Of course, the nexus between rulership, foxes, and female sexual potency was not simply conjured by Japanese retellings of Chinese narratives. In her study on fox cults and the history of their development, Kang Xiaofei notes that since the Han period (206 BCE - $220 \mathrm{CE}$ ) various Chinese sources had recorded association between fox cults and rulership, as well as foxes and sexually alluring women (and men). Over time the two motifs converged, particularly in folk tales and anecdotes written by the literati. These ideas were, in fact, so prevalent, Kang notes, that "[P]eople from all walks of life consciously manipulated gendered images of the fox to negotiate the moral and political order in the family and local community and to construct the relationship between state and society" (Kang, 2006, p. 5).

I2 Hanzoku 班足太子 is the Japanese rendering of the Indian legendary king Kalmapasada, featured in the apocryphal Benevolent King Sutra 仁王経 (full title: Benevolent King Perfection of Wisdom Sutra 仁王般若波羅蜜 經). He worshipped a graveyard deity who required him to sacrifice one thousand kings. Having slain nine hundred ninety-nine kings, the final of his chosen victims performed a Buddhist chant about the truth of impermanence causing Kalmapasada to reach enlightenment and spare the lives of all would-be victims. (Ito, I983, p. 228) 
that Emperor Toba from the Tamamo stories and Sesshōseki was one of the key players in the succession dispute that lead up to the Hōgen rebellion (I I 56), which in turn paved the way to the aforementioned Gempei War and the collapse of the aristocratic rule in Japan replaced by the dominance of the warrior class - the samurai (Goff, I997, p. 68). That would mean that, even though Toba's life in the story was spared, Tamamo was successful in exerting her nefarious influence and planting the seed of the damage she sought to cause. Furthermore, the various Otogizōshi versions of the tale end in a subtle portend of the ruin of the Heike, ${ }^{\mathrm{I} 3}$ further tangling together Toba's and Kiyomori's destiny. Thus, in all three narrative strands (Indian, Chinese, and Japanese) the seduction by a vulpine enchantress is equated with an ambition of a powerful foreign/Other deity, dramatically affecting the destiny of both the imperial (human) and religious (divine) orders.

The literary lore weaves a legend around Lady Tamamo and constructs her identity with deliberate and careful amalgamation of themes following a specific logic. Her character is pieced together by pulling from Japanese, Chinese, and Indian traditions,

${ }^{13}$ In Tamamonomae monogatari, which predates Sesshoseki, thus safe to assume to have at least been known to the playwright if not directly used as a source, several objects associated with either imperial reign or religious worship are found in Tamamo's vulpine body after she was killed by the royal archers Miuranosuke and Kazusanosuke. Some of these are then gifted to the men responsible for killing her, among which a red needle and a white needle found in the fox's tail were presented to Kazusanosuke. Having an unexplained grudge with the Taira clan, Kazusanosuke ends up gifting one of the needles to Minamoto no Yoritomo, who lead the Minamoto successfully against the Taira in the Gempei war. While Tamamonomae monogatari is vague on this, a later variant, Tamamonomae sōshi explicitly states that "[I]t was because Yoritomo gained possession of this needle that he mounted a rebellion and chastised the Taira [...]" (trans. Laura Nüffer, in Kimbrough \& Shirane, 2018). In her analysis of the Otogizōshi Tamamo tradition, Iwagi Yoriko suggests that the demise of Tamamo at the hands of the royal archers, who represent the up-and-coming samurai class, not merely foreshadows the shift in power from the aristocratic lineages and the Taira to the Minamoto, but that the fox hunt and its killing are a ritual purification of a malevolent force, which directly challenges not just political but also the religious authority of the emperor (Iwagi 2005, pp. 47-48). 
drawing associations with the fox motif in its multifaceted and ambiguous character of being both demonic and divine, both dangerous and enchanting. ${ }^{14}$ Furthermore, the trajectory of her temporal and spatial border-crossing (India through China to Japan), places Tamamo squarely within the framework of the history of Buddhist transmission in East Asia, with its teleological conclusion in Japan. Posited as the mysterious Other intent on taking down the Three Kingdoms one by one, she is simultaneously a threat to Buddhist order as such. True to her own words, her movement across space(s) and (life)time(s) destabilizes both the imperial law and the Buddhist law, and this is precisely how it is phrased in play. This way the Tamamo legend combines elements from differing sources to consolidate a narrative of boundary-crossing and order-disrupting, sealing this development in Sesshōseki by placing that narrative into Tamamo's own first-person voice. This rhetorical move creates a discursive framing within which Japan provides the stage (both metaphorical and literal) for diegetic and performative integration and completion of the narrative development that the entire Tamamo legend represents. It has Tamamo herself re-appear and narrate a reminder of her (mis)deeds when all of their implications have actualized, which cements the legitimacy of the tale for the Japanese audiences.

Tamamo, however, does not merely move across borders; she transforms across them as well, and her spatial and temporal movement is coupled with transformation and/or potential for multiple transformations. This is significant because, as Michael

${ }^{14}$ In Chinese sources all these facets of the fox are present; the folk tales and anecdotes written by the literati are more sympathetic, and the local beliefs paint foxes in a positive light, while Buddhist (particularly Ch'an) and Daoist texts emphasize the demonic side of the fox (see Kaifeng, 2006). In Japan similarly, the fox is viewed as both benevolent and malevolent, both divine and demonic. For example, in the Japanese native Shintō tradition, the fox is the object of worship in the powerful Inari cult, while the "Wild Fox Kōan" was an influential object of meditative practice in Zen Buddhism (see Smyers, I998, Heine, 2000, and Sakaita, I996). Finally, many of these characteristics of the fox are not only present in the East Asian tradition, but across the globe. For a detailed discussion on fox motif in world literature and folklore, see Uther (2006). 
Bathgate points out, "[A]s a boundary-crosser, the actions of shapeshifters like Lady Tamamo appear to challenge some of the most fundamental social and ontological categories within which we live our lives" (Bathgate, 2003, p. I2). Tamamo is an animal and non-animal; she is human and non-human; she is a god(ess) and a demon; and, eventually, in the form of the murderous stone, even animate and inanimate, all at the same time. In this context, casting the protagonist as the fox, whose very nature can be defined as being a boundary-transgressor, makes an obvious choice, and this aspect of her character is all the more compelling and significant. In fact, the act of shape-shifting and transformation is boundary-crossing par excellence, but it does not come without consequences for the crosser. That is, the transformation (actual or figurative) cannot actuate crossing without affecting the crosser. Moreover, “...the metamorph's (b)order crossing frequently works to highlight, even reinforce, the very boundaries it transgresses" (Bathgate, 2003, p. II). The way this is achieved in the play is by first allowing Tamamo to freely shift identities from spirit to fox to woman and back, and then denying her that ability. She is ultimately forced into her most dramatic and, arguably, most order-upsetting "crossing," being transformed into a shapeless, lifeless, mundane, immovable mass - everything so wholly opposite to who she originally is. However, even this transformation is not finite. In fact, this is where the Nob play picks up the story, focusing on Tamamo's afterlife, and places it into a new framework by introducing the monk Gennō and having the malevolent fox spirit of Tamamo interact with him.

This return of Tamamo, the embodiment of a subversive force that caused political instability and brought about misfortune and danger to the Japanese imperial state that symbolized the unity of the socio-political order and Buddhist regimen, is a terrifying reminder of the ever-lurking danger she brings. As the Nob convention would have it, the only one who can truly subdue her is the representative of the Buddhist order. However, it is Tamamo who approaches Gennō the priest, it is she who wants to be enlightened: the demon assumes agency by approaching the priest in search of salvation and is in control of the process. 


\section{Hammer of the Buddha: Breaking the Stone, Finding the Jewel}

The discussion so far has focused on the main protagonist of the play, Lady Tamamo. Most scholarly treatments of Sesshōseki and the Tamamo narrative tradition, in fact, have done the same. ${ }^{15}$ It is not difficult to imagine why - apart from simply being a more narratively rich, interesting, and provocative character, she neatly fits into discourses of gender and sexuality, identity and boundary-crossing, analyses of poetic allusions and visual references, among others. This is, in no small part, due to her association with the fox myth with all its connotations of metamorphosis and trickery. By contrast, the other protagonist of the play, monk Gennō, lacks the literary pedigree, and his background, while noble, is all too commonly human. In the play, he is seen as the representative of the Order; he exorcises the spirit of the Killing Stone, he is the force for good, and bringer of (en)light(enment). I propose an alternative interpretation of Gennō, in which convention itself is used to subvert the very convention it purports to follow. I suggest that this is done by complicating the reading of the typified language used to describe him, and interrogating the expected positioning vis-à-vis his counterpart Tamamo, particularly in terms of gender, center/margin binary, and religious authority.

The play opens with Gennō and his somewhat unusual michi$y u k i$. The michiyuki (道行), the travel sequence, has the function of setting the spatial confines of a play, which in Nob is particularly important, given its convention of being performed on a bare stage with minimal props and paucity of visual clues. The protagonist would narrate his/her travel, often specifying the season, time of day, and particularly places he or she has seen during the travel. The descriptors used in a michiyuki, however, are replete with allusions that provide not just the spatial, but ideological and psychological framing for the play and its protagonists. Gennō's michiyuki atypically foregoes the details of the travel itself, save for the point of departure and arrival, and focuses on this second, more abstract level. In other words, he does not focus on sites or sights, but his experiences of them:

I5 See Bathgate, 2003; Goff, I997; Faure, I996 among others. 
Let me traverse this floating world, my heart invited by clouds and water, my heart drawn forth by water and clouds.

I am Gennō, the one on the Path. Intent on achieving enlightenment, I have not strayed from the teachings of my lineage. Finally rid of affliction and delusion, I preach to people far and wide. I spent some time in Ōshū, but decided to go to the capital for the winter ascetic retreat.

My unstable self like water and clouds, my unstable self like water and clouds, wandering bewildered in the floating world of suffering. Having not reached the full depth of my mind I passed the Shirakawa barrier and arrived in Nasu-no-hara that glistens like the frost, I arrived in Nasu-no-hara in Shimotsuke province. ${ }^{\mathrm{I}}$

While Gennō, by virtue of the generic convention, is in the reader's/ viewer's mind contrasted with Tamamo and, as discussed earlier, supposed to represent Order to her Chaos, his monologue draws some obvious and significant parallels with his counterpart. His self-introduction and the references he makes mark him, too, as a creature of movement and transformation. He likens himself with clouds and water (雲水), and evokes imagery of movement, such as drifting (迷い行く), floating (浮く), wandering (旅に出る), all of which are references to the Buddhist concept of impermanence and an emblematic way of referring to traveling monks, but they also evoke the themes of boundary crossing; Genno has passed the boundary at Shirakawa river, and his travelling trajectory takes him from the Eastern provinces, which in this historical and cultural context represent the Margin, to the capital, i.e. the Center.

The image of Gennō and movement is further bolstered by the reputation of the historical Gennō, who as an adept of the Sōtō Zen lineage, was heavily involved in traveling for proselytizing, gathering solicitations for building temples, as well as practicing mountain asceticism. The latter two, while not explicitly noted in the play, are, nevertheless, copiously documented in the historical and temple records (Ishikawa, I984; Ueno, 20I3). Apart from movement, Gennō particularly insists on his status as a drifting, unstable (定めなき) self (身), lost in this world, evoking imagery of malleability and transformation: water and clouds, clouds and frost, river and frost, all are words used in the michiyuki to

${ }^{16}$ My translation. (Sanari I930, p. I635). 
refer to Gennō's person and the space he occupies (physically and spiritually), and all bring forth the imagery of water and air condensing and freezing and changing from one into the other.

In Noh, the distribution of central roles is typically between shite, the protagonist, and waki, the counterpart. ${ }^{17}$ These are in no way "stock characters," but in a tradition marked by a strong emphasis on conventional treatment of content, structure, and language, they always come with a set of presuppositions. In Sesshoseki, Tamamo is the shite to Gennō's waki, which already defines their relationship in a particular way, and creates certain expectations for the audience. In a play in which a female spirit is confronted by a Buddhist monk this is all the more true, due to the underlying power and gender dynamics. In her own consideration of boundaries in Noh, Gerry Yokota focuses on gender polarities, and considering female protagonist/Buddhist monk polarity she ponders whether the conventional relationship in which the social and religious dominance rests with the man, can become more equal, or even reversed (Yokota, 20I6, p. 78). While Yokota directs this query particularly to the third category Noh, where the shite is a ghost of a human woman, and not a demonic entity as in the fifth-category Sesshōseki, her question, I believe, is a profitable venue to explore here, as treatment of Lady Tamamo and Genno's relationship and rapport destabilizes the traditional convention.

By the time Gennō and Tamamo meet, the initial definitions of their personhoods, and the audiences' perceptions of them as polar opposites have gradually shifted. Drawing on generic conventions of Noh, their positionalities are first presented as a malevolent spirit/deluded entity versus the monk on the Buddha path. Then, as we see Tamamo's movement and transformation paralleled by Genno's, narrative of impermanence and instability, it emerges that the nature of the two figures overlaps. Finally, the

${ }_{17}$ The shitelwaki relationship in Nob is difficult to define, as it defies the usual relational structuring in most other types of drama and fiction, especially the ones belonging to the Western traditions (such as "protagonist/antagonist," "hero/villain," etc.). I use the terms "protagonist" for shite, and "counterpart" for waki as I believe they come close to reflecting the relationship of simultaneous conflict, dependence, identification, and anything and everything in between. 
reversal of the roles between the two happens on several levels. This is demonstrable in how the two are aligned with Margin/ Center. While numerous aspects of the vulpine Tamamo designate her as a creature of the Margin, the opposite is also true. Tamamo, while moving, always associates herself with the Center and those who symbolize and represent it. She is a beloved and influential consort to kings and princes, or even a deity they worship, as seen in discussion above. Gennō, on the other hand, is a traveler without fixed abode; he represents the margin while she is center(ed). In fact, both characters move back-and-forth between their central(izing) and marginal(izing) identities. In a more dramatic way, this reversal is seen in the first encounter between the two protagonists, which begins with a spatial prohibition: Gennō is not to approach the stone. This, of course, is justified as necessary for his own protection, but at the same time it is a revealing commentary on the power positioning between the two. In the most basic sense, it is an injunction against violating a boundary, as it foreshadows the danger of violating certain spatial confines, and hints at consequences arising from it. This injunction is implemented by (the ghost of) Tamamo, ostensible bringer of Chaos, and not Gennō, ostensible representative of the Order. Furthermore, according to the Killing Stone folk tradition, the noxious rock marks the separation between this world and the Other, so in an ironic twist, the ultimate boundary crosser has literally become a boundary.

Even the final scene of the play, where Gennō holds a Buddhist service for the spirit of the stone to pacify it, is not uncomplicated. In her final proclamation of retiring her "demon form": 鬼 神の姿は失せにけり (Sanari, I930, p. I846) (kijin no sukata ha usenikeri "the form of the demon is gone!") the character used is 鬼神 (kijin), which is a combination of 鬼, meaning “demon” (also "angry spirit"), and 神, designating deity (also "pacified" or "deified spirit"). In fact, the term kijin itself, does not necessarily refer to a malevolent demon, but a "fierce deity," and foxes in Japan have, historically, been understood in precisely that way. The fox has a long-standing association with rice fields and rice field deities (Smyers, I998, p. 75-78), and as such is a force for the culture and not chaos. In that sense, it is a symbol of fertility 
and not death and destruction. On the other hand, through her incarnation as Dakiniten, as discussed earlier, the fox is associated with graveyards and corpses. Thus, drawing on these opposite but complementary associations, we can read Tamamo as a kijin, who mediates life and death through interplaying these two symbolic orders. Therefore, rather than a Buddhist priest, Gennō, in this particular case acts as a traditional Japanese Shintō ritualist, and pacifies, not the alien Other disruptive deity, but the very indigenous fierce goddess that is Tamamo. Discussing representations of alterity in the Tantric Buddhist discourse, David B. Gray notes that " $[\mathrm{R}]$ eligious identity $[\ldots]$ is not monolithic but relational, developing and changing through the encounters that continually occur between competing religious traditions" (Gray, 2005, p. 45). The boundary-crossing that Tamamo and Gennō achieve together, is such an overlapping of religious codes.

\section{Conclusion: Noh Boundaries}

In Sesshōseki, border-crossing is presented as a mode of action that destabilizes Order, while also providing a means to reestablish it. Utilizing movement and transformation as modes of boundary-crossing, the play problematizes a number of social, historical, and religious issues. These are personified in the characters of the protagonist and her counterpart, and worked out through their interaction. Lady Tamamo is constructed as a subversive figure who upsets and disrupts the boundaries that establish, support, and maintain Order. The established order is one of superiority of human over non-human, male over female, ignorant over enlightened, domestic (Japanese) over foreign (continental), Center over Margin. Tamamo repeatedly crosses all these boundaries and upsets the Order. Katherine Pratt Ewing suggests that we can look at our very categories as "borderlands," sites of negotiations (Ewing, I998, p. 263). Tamamo embodies several overlapping categories as she moves and transforms across boundaries on multiple levels both synchronically (ontologically) and diachronically (over time). The body of a shape-shifter like Tamamo represents a site for negotiating and resolving crises in understanding the long held, entrenched categories. On the one hand she moves through multiple identities, imperial reigns, 
continents and realms, while at the same time collapsing time and space and those identities, effectively erasing the boundaries between them.

Gennō, the proponent of the dominant religious regimen, acts as her foil and deterrent. However, as shown in the analysis of his michiyuki, he is himself a moving and shifting entity. A Buddhist monk without fixed abode, drifting and floating, having not yet reached the depth of his mind, he embodies ruptured Order. It is this vulnerability that makes the relationship between the two characters particularly interesting and significant. While on the surface this relationship plays out according to convention, when all the underlying subtext is taken into account (narrative tradition, linguistic connotations, performative structure) what it exactly means to say that Order is disturbed and reestablished invites deeper inquiry.

Nob lends itself particularly well to this kind of analysis, due to its own boundary-crossing characteristics, being at once literature, performance, religious text, and ritual. It weaves narratives from multiple sources, often generically quite diverse, into a tapestry that makes a narrative in its own right but relies on its predecessors for full meaning and significance. As a performance it overlaps dramatic acting with elements of religious ritual, and in its own way, dance and music. Acting technique in Nob is a part of this conversation as well, and contributes to the possibility of narrative expression, as "Body in Nob [is] a flexible processual site," where "phenomenal world [is] perceived as a living body" (Amano, 20II, p. 530). This is why Tamamo and, indeed, Gennō can be the sites of different kinds of "crossings." They are characters in a narrative, performers on the stage, and participants in a ritual. The narrative (or rather narratives, as we have seen multiple narrative threads woven together) provides the dimension of probing the historical context and socio-political structure of aristocracy/samurai transition. The ritual context of Noh coopts Gennō's status as a Buddhist figure and places him within the demon-pacifying ritual structure, complicating the relationship between overlapping religious traditions (Buddhist and non-Buddhist). Precisely due to its generic characteristics, Noh provides the stage, literal and metaphorical, 
on which competing regimens, orders, and Orders can interplay with each other. The order is established dialectically as the new Order, while the process of ordering is a reconfiguration of the preceding one.

Boundary crossing in Noh occurs in a way that boundaries are being transcended, but the reality is being reconfigured, not as disturbance of order, but as a constant process of ordering and reordering, in other words - unbounding. However, this process is simultaneously a process of (re)bounding establishing boundaries that will be unbounded. This allows for the audience to remain comfortable with their categories that are seemingly reified. This process is deeply subversive in that sense, as it completely unravels the plane of reality while keeping the strings seemingly together. Narratives of boundary-crossing create an epistemological frame where nothing is as it seems, and reality is fragmented and unstable. Unbounding would rather be creating an alternative order through boundary-crossing reconfigured as un-bounding.

\section{References}

Amano, Y. (20II). “Flower' as Performing Body in Nō Theatre," Asian Theatre Journal, 28, pp. 529-548.

Bathgate, M. (2003). The Fox's Craft in Japanese Religion and Culture: Shapeshifters, Transformations, and Duplicities. New York: Routledge.

Brazell, K. (I999). Traditional Japanese Theater, Revised ed. New York: Columbia University Press.

Butler, L. A. (I996). "The Way of Yin and Yang. A Tradition Revived, Sold, Adopted," Monumenta Nipponica, 5I(2), pp, I 89-2 I 7.

Ewing, K. P. (I998). "Crossing Borders and Transgressing Boundaries: Metaphors for Negotiating Multiple Identities," Ethos, 26(2), pp. 262-267.

Faure, B. (2015). Gods of Medieval Japan: Protectors and Predators. Honolulu: University of Hawaii Press.

Goff, J. (I997). "Foxes in Japanese Culture: Beautiful or Beastly?” Japan Quarterly, 44(2), pp. 66-77. 
Gray, D. B. (2005). "Eating the Heart of the Brahmin: Representations of Alterity and the Formation of Identity in Tantric Buddhist Discourse," History of Religions, 45(I), pp. 45-69.

Heine, S. (2000). Shifting Shape, Shaping Text: Philosophy and Folklore in Fox Koan. Honolulu: University of Hawaii Press.

Ishikawa, R. (I984). “Genno Shinsho to sanrinryo," Indogaku bukkyogaku kenkyu, 32(2), pp. 597-602.

- (I982). "Chuse sotoshu no chiho tenkai to Genno Shinsho," Indogaku bukkyogaku kenkyu, 3 I (I), pp. 227-23I.

Itō, M. (I983). Yōkyokushū / Itō Masayoshi kōchū, Shinchō Nihon koten shūsei. Tōkyō: Shinchōsha.

Iwagi Y. (2005). “Tamamo no mae monogatari no kenkyu," Ryukoku daigaku daigakuin bungaku kenkyuka kiyo, 27, pp. 405-408.

Kaifeng, X. (2006). The Cult of the Fox: Power, Gender, and Popular Religion in Late Imperial and Modern China. New York: Columbia University Press.

Kimbrough, K. \& Haruo, S. (2018). Monsters, Animals, and Other Worlds: A Collection of Short Medieval Japanese Tales. New York: Columbia University Press.

Minobe, S. (I982). "The World View of 'Genpei Jōsuiki'," Japanese Journal of Religious Studies, 9(2-3), pp. 213-233.

Nienhauser, W. Jr. (ed). (I994). The Grand Scribe's Records. Bloomington: Indiana University Press

Sanari, K. (I930). Yōkyoku taikan, Vol 5. Tōkyō: Meiji Shoin.

Sakaita, H. (I996). "Nicchu kitsune bunka no tansaku," Chukyo daigaku kyoyo ronso, 36(4), pp. I 292-1330

Smyers, K. (1998). The Fox and the Jewel: Shared and Private Meanings in Contemporary Japanese Inari Worship. Honolulu: University of Hawaii Press.

Ueno, N. (2013). "Zoku fuso zenrin so hoden ni miru Genno Shinsho," Indogaku bukyogaku kenkyu, 6I (2), pp. 560-563.

- (2010). "Genno Shinsho kaiso no dewa shohoji ni nokoru denki shiryo ni tsuite," Indogaku bukyogaku kenkyu, 58(2), pp. 722-725. 
Uther, H.J. (2006). "The Fox in World Literature: Reflections on a 'Fictional Animal'," Asian Folklore Studies, 65(2), pp. I33-I60.

Yokoi, K. (I999). "Sesshoseki densetsuko: shukyo jinruigaku no hoho to shiza kara," Komazawa daigaku bukkyo gakubu ronshu, 30, pp. 29I-309.

Yokota, G. (2016). "The Rhetoric of Noh: Border Crossings in Karukaya and Tadatsu no Saemon and Beyond," Gengo bunka kyodo kenkyu purojekuto, pp. 77-88.

Yokoyama, S. \& Matsumoto R. (I98I). Muromachi jidai monogatari taisei, vol. 9. Tokyo: Kadokawa Shoten. 